\title{
PENGARUH REKRUTMEN TERHADAP KINERJA PERANGKAT PEMERINTAH DESA SUNGAI TOHOR BARAT DAN DESA SENDANU DARUL IHSAN
}

\author{
Al Zhikri \\ IImu Pemerintahan FISIPOL Universitas Abdurrab \\ Alzhikri793@gmail.com
}

\begin{abstract}
Abstrak
Proses rekrutmen dengan nepotisme mengakibatkan ketidakadilan dalam mendapatkan peluang menjadi salah satu perangkat desa. Dengan demikian, perlu proses rekrutmen yang terbuka dari stakeholder agar mendapatkan hasil yang baik. Penelitian ini bertujuan untuk menguji apakah ada pengaruh rekmutmen perangkat desa terhadap kinerja perangkat pemerintah desa di Desa Sungai Tohor Barat dan Desa Sendanu Darul ihsan. Penelitian ini menggunakan metode kuantitatif eksplanasi. Metode pengumpulan data yang digunakan adalah dengan survei dengan menyebarkan angket kepada 95 responden. Peneliti menggunakan teori rekrutmen menurut Simamora (2014) dan kinerja menurut Agus Dwiyanto (2008). Hipotesis penelitian di uji dengan menggunakan analisis regresi linear sederhana. Hasil penilitian ini menunjukkan adanya pengaruh rekrutmen terhadap kinerja perangkat desa di Desa Sungai Tohor Barat dan Desa Sendanu Darul Ihsan, yaitu sebesar 0,163 atau 16,3\%. Nilai pengaruhnya tidak terlalu besar, artinya ada variabel-variabel lain yang turut menentukan kinerja perangkat desa yang tidak menjadi objek kajian penelitian ini.
\end{abstract}

Kata kunci: rekrutmen, kinerja perangkat desa, Desa Sungai Tohor Barat, Desa Sendanu Darul Ihsan

\begin{abstract}
Recruitment process with nepotism resulted in injustice in getting village officials. Thus, an open recruitment process from stakeholders is needed to get good results. This study aims to examine whether there is an influence of village apparatus recruitment on the performance of village government in the Sungai Tohor Barat and Sendanu Darul ihsan Villages. This study uses quantitative explanatory methods. The data collection method used was a survey by distributing questionnaires to 95 respondents. The researcher used the recruitment theory according to Simamora (2004) and performance according to Agus Dwiyanto (2008). The research hypothesis was tested using simple linear regression analysis. The results of this research indicate the influence of recruitment on the performance of village officials in Sungai Tohor Barat and Sendanu Darul Ihsan Villages, amounting to 0.163 or $16.3 \%$. The value of influence is not too large, meaning that there are other variables that determine the performance of the village apparatus that are not the object of this research study.
\end{abstract}

Keywords: recruitment, village officials' working performance, Sungai Tohor Barat, Sendanu Darul Ihsan

\section{PENDAHULUAN}

Negara Indonesia merupakan negara kesatuan dan berkedaulatan rakyat.Negara kesatuan adalah negara yang tidak tersusun daripada beberapa negara, melainkan negara itu sifatnya tunggal (satu), artinya hanya ada satu negara, dan tidak ada 
negara dalam negara. Dalam negara kesatuan itu juga hanya ada satu pemerintahan, yaitu pemerintahan pusat yang mempunyai kekuasaan atau wewenang tertinggi dalam segala lapangan pemerintahan. Negara Kesatuan Republik Indonesia (NKRI) merupakan negara kesatuan yang menganut asas desentralisasi dalam penyelenggaraan pemerintahan di daerah, dengan memberikan kesempatan dan keleluasaan kepada daerah untuk menyelenggarakan otonomi daerah.

Berdasarkan Undang-Undang No. 32 Tahun 2004 dan Undang-Undang No. 12 Tahun 2008 yang telah disempurnakan dengan Undang-Undang No. 23 Tahun 2014 tentang pemerintah daerah khususnya pasal 1 ayat 6 menyebutkan bahwa otonomi daerah adalah hak, wewenang, dan kewajiban daerah otonomi untuk mengatur dan mengurus sendiri urusan pemerintahan dan kepentingan masyarakat setempat sesuai dalam sistem Negara Kesatuan Republik Indonesia (NKRI). Dalam pemberian peluang seluas-luasnya kepada daerah atau dengan kata lain pembagian kewenangan daerah terlihat jelas dalam pasal 200 ayat 1 Undang-Undang No. 32 Tahun 2004 tentang pemerintah daerah menyebutkan bahwa dalam pemerintahan daerah kabupaten/kota dibentuk pemerintahan desa terdiri dari pemerintah desa dan Badan Permusyawaratan Desa (BPD). Berdasarkan Undang-Undang No. 32 Tahun 2004 tersebut, pemerintah mengeluarkan Peraturan Pemerintah (PP) No. 72 Tahun 2005 tentang desa, yang sekarang telah disempurnakan dengan Undang-Undang No. 6 Tahun 2014 tentang desa, dengan demikian desa diberi kewenangan khusus untuk mengatur dan mengurus rumah tangganya sendiri yaitu otonomi desa.

Menurut Widjaja (2005) otonomi desa merupakan otonomi yang asli, bulat dan utuh serta bukan merupakan pemberian dari pemerintah.Sebaliknya pemerintah berkewajiban menghormati otonomi asli yang dimiliki desa tersebut.Pelaksanaan otonomi desa tertera dalam Undang-Undang No. 6 Tahun 2014 tentang desa. Dalam pasal 1 ayat 3 menerangkan bahwa pemerintah desa adalah kepala desa atau yang disebut dengan nama lain dibantu perangkat desa sebagai unsur penyelenggara pemerintahan desa. Pada pasal 48 menyebutkan bahwa perangkat desa terdiri dari sekretariat desa, pelaksana kewilayahan, dan pelaksana teknis yang bertugas membantu kepala desa dalam melaksanakan tugas dan wewenangnya.Seperti yang diketahui bahwa perangkat desa diangkat berdasarkan keputusan dari kepala desa.Pengangkatan perangkat desa secara umum memuat tentang persyaratan 
calon, mekanisme pengangkatan, masa jabatan, kedudukan keuangan, uraian tugas, larangan, dan mekanisme pemberhentian.

Kabupaten Kepulauan Meranti masih mengacu pada Peraturan Pemerintah (PP) No. 72 Tahun 2005 tentang desa, berdasarkan Pasal 13 Peraturan Pemerintah No. 72 Tahun 2005 tentang desa, menyebutkan bahwa ketentuan lebih lanjut mengenai pedoman penyusunan organisasi dan tata kerja pemerintahan desa diatur dengan peraturan daerah kabupaten/kota. Kemudian dari acuan Peraturan Pemerintah (PP) tersebut, dikeluarkanlah Peraturan Daerah Kepulauan Meranti (PERDA) No. 12 Tahun 2011 tentang pedoman penyusunan organisasi dan tata kerja pemerintahan desa, telah menjelaskan bagaimana proses pelaksanaan rekrutmen perangkat desa, mulai dari pembentukan panitia pelaksana rekrutmen perangkat desa, penjaringan, penyaringan, hingga pellantikan dan serah terima jabatan perangkat desa. Apabila masih terjadi kekeliruan maupun kendala dalam pelaksanaan rekrutmen perangkat desa, menjadi pertanyaan bagi masyarakat dan refleksi bagi panitia pelaksanaan rekrutmen maupun unsur yang terlibat di dalamnya

Berkaitan dengan Undang-Undang Desa No. 6 Tahun 2014 dan Peraturan Menteri Dalam Negeri (PERMENDAGRI) No 83 Tahun 2015 tentang pengangkatan dan pemberhentian perangkat desa lainnya, pemerintah kabupaten belum melakukan pembaruan peraturan daerah mengenai perangkat desa. Dengan demikian desa yang ada di Kecamatan Tebingtinggi Timur masih menggunakan Peraturan Menteri Dalam Negeri (PERMENDAGRI) No. 83 Tahun 2015 tentang pengangkatan dan pemberhentian perangkat desa lainnya. Pada Undang-Undang No. 6 Tahun 2014 pasal 1 ayat (3) pemerintah desa adalah kepala desa atau yang disebut dengan nama lain dibantu perangkat desa sebagai unsur penyelenggaraan pemerintah desa. Dalam menyelenggarakan urusan-urusan tersebut kepala desa dibantu oleh perangkat desa yaitu terdiri dari sekretaris desa dan perangkat desa lainnya. Dan lebih rinci sesuai dengan penelitian ini, tentang perangkat desa lainnya, atau diluar desa, bahwa perangkat desa lainnya sebagaimana dimaksud pada Undang-Undang No. 6 Tahun 2014 tentang desa pasal 48 terdiri dari; Sekretariat desa, Pelaksana teknis lapangan, dan unsur kewilayahan.

Dalam memperoleh perangkat desa yang berkompeten dan berkualitas, seluruh kepala desa di Kecamatan Tebingtinggi Timur Kabupaten Kepulauan Meranti menerapkan mekanisme pengangkatan perangkat desa yang tertera dalam 
Peraturan Kepala Desa (PERDES) pada masing-masing desa, tentang tata tertib pengangkatan perangkat desa lainnya. Dalam menentukan kemajuan suatu desa, partisipasi masyarakat dan perhatian masyarakat sangat diperlukan. Patisipasi dapat menciptakan suatu roda pemerintahan desa berjalan dengan baik. Masyarakat juga salah satu lembaga yang mengawasi jalannya suatu roda pemerintahan. Pengawasan dilakukan agar pemerintahan berlandaskan masyarakat itu sendiri. Pengawasan yang dilakukan oleh masyarakat dari semua aspek pemerintah, termasuk proses rekrutmen perangkat desa juga perlu pengawasan dari masyarakat supaya mendapat perangkat desa yang berkualitas. Mengingat kedudukan perangkat desa yang penting, diperlukan juga proses rekrutmen yang tepat, agar sistem pemerintahan desa berjalan sesuai dengan aturan. Perangkat desa merupakan ujung tombak dari pemerintahan daerah yang berhubungan langsung dengan masyarakat. Dengan dinamika yang semakin maju, perangkat desa harus mampu menunjukan kinerjanya lebih baik.Sehingga efektivitas kerja bisa dipertanggung jawabkan.

Payaman Simanjuntak (2005) mengemukakan kinerja adalah tingkat pencapaian hasil atas pelaksanaan tugas tertentu. Dengan demikian diperlukan kinerja yang lebih intensif dan optimal dari bagian organisasi demi optimalisasi bidang tugas yang menjadi tanggung jawab.Pencapaian kinerja yang tinggi tidak lepas dari faktor sumber daya manusia yang ada.Hal tersebut dikarenakan sumber daya manusia (SDM) sering merupakan salah satu sorotan yang paling tajam dalam pelaksanaan pemerintahan, menyangkut kesiapan, jumlah, pendidikan, dan profesionalisme. Oleh karena itu untuk menghasilkan sumber daya manusia yang berkualitas diperlukan proses rekrutmen yang tepat.

Kenyataannya menunjukan bahwa dalam melaksanakan tugas dan tanggung jawabnya pemerintah Desa Sungai Tohor Barat dan Sendanu Darul Ihsan menghadapi beberapa kendala. Salah satu diantaranya adalah rendahnya kemampuan profesional dan etos kerja sumber daya manusia (aparatur) perangkat desa. Sehingga kinerja pemerintah desa belum dapat berjalan dengan baik. Terutama pada proses rekrutmen perangkat desa yang belum berdasarkan prinsip obyektifitas, maupun transparan. Sehingga dari proses rekrutmen yang kurang baik tersebut menyebabkan kinerja perangkat desa tidak optimal. Bila fungsi rekrutmen perangkat desa berjalan dengan baik serta berkeseinambungan, maka hasilnya 
adalah perangkat desa berkualitas yang sanggup melaksanakan pekerjaan berdasarkan peraturan perundang-undangan yang berlaku, namun yang terjadi selama ini adalah masyarakat masih mengeluh akan buruknya sistem kinerja pemerintah desa. Rekrutmen perangkat desa sendiri tidaklah sama antara satu desa dan desa lain. Pada dasarnya rekrutmen perangkat desa akan terjadi setelah ada kekosongan jabatan sehingga dilakukan rekrutmen untuk mengisi kekosongan jabatan tersebut. Hal ini sudah diatur oleh Peraturan Menteri Dalam Negeri (PERMENDAGRI) No. 83 Tahun 2015 mengenai pengangkatan dan pemberhentian perangkat desa.

Pada proses rekrutmen perangkat desa di Desa Sungai Tohor Barat dan Desa Sendanu Darul Ihsan, tokoh adat setempat dan pendamping desa menilai anggota panitia pemilihan perangkat desa masih adanya indikasi ada kecurangan. Salah satu dari kecurangan itu ialah nepotisme artinya orang/pegawai yang direkrut merupakan sanak saudara, anak, teman terdekat dan lain sebagainya dari orang yang merekrut. Demikian ini sudah menjadi rahasia umum di kalangan birokrasi. Dengan fenomena yang terjadi membuat proses rekrutmen perangkat desa di Desa Sungai Tohor Barat dan Desa Sendanu Darul Ihsan belum memasuki kategori yang baik. Fenomena yang terjadi menyebabkan efektivitas kerja perangkat desa dalam memberikan pelayanan kepada masyarakat desa menjadi terhambat. Seharusnya dengan adanya cara rekrutmen yang terbuka, artinya pola rekrutmen berdasarkan pada langkah maupun tindakan melalui proper test yang dilakukan oleh stakeholder di pemerintahan desa (kepala desa, ketua BPD, dan tokoh masyarakat), maka sistem pemerintah desa akan berjalan sesuai dengan tugas dan kewenangannya. Berdasarkan latar belakang masalah diatas, maka rumusan masalah dalam penelitian ini adalah apakah proses rekrutmen mempengaruhi kinerja perangkat pemerintah Desa Sungai Tohor Barat dan Desa Sendanu Darul Ihsan.

\section{STUDI LITERATUR}

\section{Manajemen Sumber Daya Manusia (MSDM)}

Manajemen adalah ilmu dan seni mengatur proses pemanfaatan sumber daya manusia dan sumber-sumber daya lainnya secara efektif dan efisien untuk mencapai suatu tujuan tertentu. Menurut Hasibuan (2005), MSDM adalah ilmu dan seni mengatur hubungan dan peranan tenaga kerja agar efektif dan efesien membantu 
terwujudnya tujuan perusahaan, karyawan, dan masyarakat. Manajemen ini terdiri dari enam unsur (6M) yaitu: men, money, methode, materials, machines, dan market. Unsur men (manusia) ini berkembang menjadi suatu bidang ilmu manajemen yang disebut manajemen sumber daya manusia atau disingkat MSDM yang merupakan terjemahan dari man power management.Peranan MSDM diakui sangat menentukan bagi terwujudnya tujuan, tetapi untuk memimpin unsur manusia ini sangat sulit dan rumit.Tenaga kerja manusia selain mampu, cakap, dan terampil, juga tidak kalah pentingnya kemauan dan kesungguhan mereka untuk bekerja efektif dan efisien.

\section{Rekrutmen}

Menurut Sukamti (1989) rekrutmen dalah serentetan kegiatan yang digunakan oleh organisasi untuk menarik calon pegawai yang memiliki kemampuan dan sikap yang dibutuhkan untuk membantu mencapai tujuannya. Henry Simamora (2004) menyatakan bahwa "rekrutmen (recruitment) adalah serangkaian aktivitas mencari dan memikat pelamar kerja dengan motivasi, kemampuan, keahlian dan pengetahuan yang diperlukan guna menutupi kekurangan yang diidentifikasi dalam perencanaan kepegawaian". Mathis (2006) menyampaikan penarikan (rekrutmen) pegawai merupakan suatu proses atau tindakan yang dilakukan oleh organisasi untuk mendapatkan tambahan pegawai melalui beberapa tahapan mencakup identifikasi dan evaluasi sumber-sumber penarikan tenaga kerja, menentukan kebutuhan tenaga kerja, proses seleksi, penempatan, dan orientasi tenaga kerja.

Menurut Veithzal Rivai (2009), rekrutmen pada hakikatnya merupakan proses menentukan dan menarik pelamar kerja yang mampu bekerja dalam suatu perusahaan. Proses ini dimulai ketika para pelamar dicari dan berakhir ketika lamaran-lamaran mereka diserahkan atau dikumpulkan. Hasilnya merupakan sekumpulan pelamar calon karyawan baru untuk diseleksi dan dipilih. Dengan demikian, rekrutmen adalah proses mencari, menemukan, mengajak dan menetapkan sejumlah orang dari dalam maupun dari luar perusahaan sebagai calon tenaga kerja dengan karakteristik tertentu seperti yang telah ditetapkan dalam perencanaan sumber daya manusia. Hasil yang didapatkan dari proses rekrutmen adalah sejumlah tenaga kerja yang akan memasuki proses seleksi, yakni proses untuk menentukan kandidat yang paling layak untuk mengisi jabatan tertentu yang 
tersedia di perusahaan atau kantor. Pelaksanaan rekrutmen dan seleksi merupakan tugas yang sangat penting, krusial, dan membutuhkantanggung jawab yang besar. Hal ini karena kualitas sumber daya manusia yang akandigunakan perusahaan atau kantor sangat tergantung pada bagaimana prosedur rekrutmen dilaksanakan.

\section{a. Identifikasi dan Evaluasi}

Tahap identifikasi merupakan tahap awal dari proses yang terdiri atas penentuan dari unsur-unsur yang diamati. Kegiatan ini diawali dengan melakukan analisis pekerjaan agar dapat mengenali unsur-unsur yang dapat dinilai dan dapat mengembangkan skala penilaian.

\section{1) Proses Seleksi}

Seleksi merupakan proses pemilihan orang-orang yang memiliki kualifikasikualifikasi yang dibutuhkan untuk mengisis lowongan pekerjaan di sebuah organisasi (Mathis 2006). Seleksi lebih dari sekedar pemilihan orang yang tersedia. Menyeleksi sekumpulan pengetahuan, keahlian, dan kemampuan yang sesuai merupakan suatu paket yang terdapat pada manusia untuk memperoleh "kecocokan" antara apa yang sesungguhnya dapat dilakukan dan apa yang ingin dilakukan pelamar. Adapun proses seleksi yang lazim dipergunakan oleh perusahaan, prosedurnya meliputi: wawancara awal; pengisian formulir; pemeriksaan referensi; test psikologi; wawancara/interview; persetujuan atasan langsung; pemeriksaan kesehatan; indeks atau orientasi.

\section{2) Penempatan}

Penempatan bukanlah merupakan sebuah keputusan final. Hal ini merupakan sebuah langkah awal yang terdiri dari apa yang menurut perkiraan supervisor yang bersangkutan dapat dilakukan oleh si pekerja baru dengan apa yang "diminta" oleh pekerja (dalam bentuk minat intrinsik, kesempatan untuk bekerja sama, kemungkinan-kemungkinan promosi, pembayaran atau imbalan).

\section{3) Orientasi tenaga kerja}

Orientasi dapat diartikan sebagai proses yang ditujukan untuk memperkenalkan dengan rekan-rekan kerja atau proses pengenalan dengan karyawan lama, dan 
dapat didefinisikan sebagai kegiatan untuk memperkenalkan karyawan baru dengan rekan kerjanya dan dengan organisasi, yaitu informasi mengenai tujuan, sejarah, philosophy, prosedur, dan aturan-aturan, mengkomunikasikan kebijaksanaan SDM yang penting. Tahap ini adalah langkah terakhir dari proses rekrutmen, dimana penolakan dapat dilakukan bila calon pegawai gagal selama masa orientasi atau induksi.

\section{4) Sumber penarikan}

\section{- Sumber dari Dalam Perusahaan (Internal)}

Sumber Internal menurut Hasibuan (2005) adalah karyawan yang akan mengisi lowongan kerja yang lowong diambil dari dalam perusahaan tersebut, yakni dengan cara memutasikan atau memindahkan karyawan yang memenuhi spesifikasi pekerjaan jabatan itu. Pemindahan karyawan bersifat vertikal (emosi ataupun demosi) maupun bersifat horizontal (mutasi dan rotasi).

\section{- Sumber dari Luar Perusahaan (Eksternal)}

Sumber eksternal menurut Hasibuan (2005) adalah usaha penarikan tenaga kerja dari luar perusahaan. Cara ini dinilai sangat positif, karena dengan sistem ini tenaga kerja yang diterima merupakan pilihan dari pelamar-pelamar yang telah memenuhi syarat-syarat yang ditentukan perusahaan.

Menurut Handoko (2008) ada beberapa metode atau cara untuk mendapatkan tenaga kerja dari sumber-sumber eksternal, yaitu walk-in, rekomendasi dari karyawan, iklan, agen-agen penempatan tenaga kerja, lembaga pendidikan, organisasi karyawan, nepotisme, asosiasi profesional, penyewaan (leasing), organisasi militer dan open house.

\section{5) Metode Rekrutmen}

Metode penarikan akan berpengaruh besar terhadap banyaknya lamaran yang masuk ke dalam perusahaan. Menurut Hasibuan (2005), metode penarikan karyawan baru terbagi dua yaitu:

\section{- Metode Tertutup}

Metode tertutup adalah ketika penarikan kerja diinformasikan kepada para karyawan atau orang-orang tertentu saja.Akibatnya, lamaran yang masuk 
relatif sedikit sehingga kesempatan untuk mendapatkan pekerjaan yang baik sulit.

\section{- Metode Terbuka}

Metode terbuka ketika penarikan diinformasikan secara luas dengan memasang iklan pada media massa, cetak maupun elektronik, agar tersebar luas ke masyarakat. Dengan metode terbuka, diharapkan lamaran banyak masuk sehingga kesempatan untuk mendapatkan karyawan yang qualified lebih besar.

\section{6) Kinerja}

Pengertian kinerja menurut Mangkunegara (2009) adalah hasil kerja kualitas dan kuantitas yang dicapai oleh seseorang pegawai dalam melaksanakan tugasnya sesuai dengan tanggung jawab yang diberikan kepadanya. Kinerja adalah tentang melakukan pekerjaan dan hasil yang dicapai dari pekerjaan tersebut. Kinerja adalah tentang apa yang dikerjakan dan bagaimana cara mengerjakannya. Kinerja merupakan hasil pekerjaan yang mempunyai hubungan kuat dengan tujuan strategis organisasi, kepuasaan konsumen dan memberikan kontribusi ekonomi.Menurut Kamus Bahasa Indonesia karangan Departemen Pendidikan dan Kebudayaan, kinerja dapat diartikan sesuatu yang dicapai, prestasi yang dilihatkan, kemampuan kerja (tata peralatan). Ada beberapa indikator yang biasanya digunakan untuk mengukur kinerja organisasi publik (Agus Dwiyanto 2008) yaitu sebagai berikut:

\section{- Produktivitas}

Konsep produktivitas tidak hanya mengukur tingkat efesiensi, tetapi juga efektivitas pelayanan. Produktivitas pada umumnya dipahami sebagai rasio antara input dan output.

- Kualitas pelayanan

Isu mengenai kualitas pelayanan semakin penting dalam menjalankan kinerja organisasi pelayanan publik.Banyak pandangan negatif yang muncul mengenai organisasi publik karena ketidakpuasan masyarakat terhadap kualitas layanan yang diterima dari organisasi publik.

\section{- Responsif}


Responsif adalah kemampuan organisasi mengenai kebutuhan masyarakat, menyusun agenda dan prioritas pelayanan dan mengembalikan programprogram pelayanan publik sesuai dengan kebutuhan dan aspirasi masyarakat.

\section{- Responsibilitas}

Responsibilitas menjelaskan apakah pelaksanaan kegiatan organisasi publik itu dilakukan sesuai dengan prinsip-prinsip administrasi yang benar atau sesuai dengan kebijakan organisasi, baik yang eksplisit maupun implisit.

\section{- Akuntabilitas}

Akuntabilitas digunakan untuk melihat kebijakan dan kegiatan organisasi yang berpegang teguh pada masyarakat.Kinerja organisasi mempunyai tingkat akuntabilitas yang baik. Organisasi melaksanakan kegiatan tidak bertentangan dengan norma-norma yang berlaku dalam masyarakat.

\section{METODE PENELITIAN}

Pendekatan dalam penelitian ini adalah pendekatan kuantitatif, karena penelitian ini disajikan dengan angka-angka. Hal ini sesuai dengan pendapat Arikunto (2006) yang mengemukakan penelitian kuantitatif adalah pendekatan penelitian yang banyak dituntut menggunakan angka, mulai dari pengempulan data, penafsiran terhadap data tersebut, serta penampilan hasilnya. Jenis penelitian ini adalah penelitian kuantitatif eksplanasi.Penelitian ini bermaksud untuk menjelaskan suatu generalisasi sampel terhadap populasinya atau menjelaskan hubungan, perbedaan atau pengaruh satu variabel dengan variabel lainnya.Bentuk penelitian ini adalah penelitian lapangan (field research) di mana peneliti melebur dengan obyek penelitian dengan menggunakan teknik survei dalam pengumpulan data.

Penelitian ini dilaksanakan di di Desa Sungai Tohor Barat dan Desa Sendanu Darul Ihsan Kecamatan Tebingtinggi Timur Kabupaten Kepulauan Meranti.Populasi adalah wilayah generalisasi terdiri atas obyek atau subyek yang mempunyai kualitas dan karakteristik tertentu yang ditetapkan oleh peneliti untuk dipelajari dan kemudian ditarik kesimpulannya (Sugiyono 2009). Dengan demikian, yang menjadi populasi dalam penelitian ini adalah seluruh masyarakat di Desa Sungai Tohor Barat dan Desa Sendanu Darul Insan yang berjumlah 1,893. Dengan sampel penelitian diambil dai populasi menggunakan rumus Slovin sebesar 95 reponden. Metode 
pengumpulan data yang digunakan adalah dengan survei dengan menyebarkan angket tertutup kepada 95 responden. Data di peroleh adalah data kuantitatif atau data berbentuk angka.Untuk mengukur variabel dalam penelitian ini digunakan model Skala Likert. Setiap pertanyaan atau pernyataan tersebut diungkapkan dengan kata-kata: Sangat Tidak Setuju (STS), Tidak Setuju (TS), Netral/ragu-ragu (N/RG), Setuju (S), dan Sangat Setuju (SS) (Supranto 2011).

\section{PEMBAHASAN}

\section{Uji Instrumen Peneilitian}

\section{a. Uji Validitas}

Uji validitas adalah sebuah pengujian yang di tujukan untuk menunjukkan sejauh mana suatu alat ukur atau instrumen penelitian dapat mengukur apa yang diukur (Siregar 2015:75). Validitas suatu pernyataan dalam angket dapat dilihat dengan menghitung $r_{\text {hitung }}$ dan membandingkan dengan nilai $r_{\text {tabel }}$ metode pearson correlation. Apabila nilai $r_{\text {hitung }}>r_{\text {tabel }}$ maka item pertanyaan dinyatakan valid dan apabila nilai $r_{\text {hitung }}<r_{\text {tabel }}$ maka item pertanyaan dinyatakan valid atau dengan membandingkan nilai signifikasi apabila nilai sig. (2-tailed) > 0,05 maka item dinyatakan valid. Pada penelitian ini, peneliti mengambil 20 sampel untuk dijadikan bahan validitas. $\mathrm{Df}=\mathrm{N}-2 . \mathrm{Df}=(20-2)=18$, maka tabel $\mathrm{r}$ pada angka 18 Product Moment adalah 0,468. Berikut adalah hasil uji validitas menggunakan SPSS untuk variabel $\mathrm{X}$ dan $\mathrm{Y}$ :

\section{Tabel 1. Uji Validitas}

Item-Total Statistics

\begin{tabular}{|l|r|r|r|r|r|}
\hline & $\begin{array}{r}\text { Scale Mean if } \\
\text { Item Deleted }\end{array}$ & $\begin{array}{c}\text { Scale Variance if } \\
\text { Item Deleted }\end{array}$ & $\begin{array}{c}\text { Corrected Item- } \\
\text { Total Correlation }\end{array}$ & $\begin{array}{c}\text { Squared Multiple } \\
\text { Correlation }\end{array}$ & $\begin{array}{c}\text { Cronbach's Alpha } \\
\text { if Item Deleted }\end{array}$ \\
\hline X1.1 & 74,05 & 10,787 & $\mathbf{8 7 5}$ & .747 & .892 \\
X1.2 & 74,05 & 7,839 & $\mathbf{7 4 5}$ & .785 & .892 \\
X1.3 & 74,35 & 8,345 & $\mathbf{9 8 8}$ & .824 & .898 \\
X1.4 & 73,95 & 8,155 & $\mathbf{5 5 0}$ & .859 & .892 \\
X1.5 & 74,20 & 9,116 & $\mathbf{7 6 1}$ & .659 & .899 \\
X1.6 & 74,00 & 6,947 & $\mathbf{8 0 1}$ & .865 & .896 \\
X1.7 & 74,65 & 8,661 & $\mathbf{8 2 6}$ & .751 & .901 \\
X1.8 & 74,10 & 8,095 & $\mathbf{7 5 4}$ & .719 & .904 \\
X1.9 & 74,45 & 7,839 & $\mathbf{7 1 6}$ & .881 & .894 \\
X1.10 & 74,45 & 10,155 & $\mathbf{6 3 9}$ & .753 & .895 \\
Y1.1 & 74,15 & 8,258 & $\mathbf{5 3 7}$ & .762 & .806
\end{tabular}




\begin{tabular}{|l|l|l|l|l|l|} 
Y1.2 & $\mathbf{7 3 , 3 5}$ & $\mathbf{8 , 9 7 6}$ & $\mathbf{, 5 8 7}$ & .687 & .907 \\
Y1.3 & 73,80 & 8,695 & $\mathbf{, 4 9 7}$ & .915 & .889 \\
Y1.4 & 74,25 & 8,408 & $\mathbf{6 8 6}$ & .824 & .892 \\
Y1.5 & 73,85 & 8,661 & $\mathbf{4 7 6}$ & .859 & .892 \\
Y1.6 & 73,60 & 8,253 & $\mathbf{5 5 3}$ & .738 & .898 \\
Y1.7 & 73,60 & 9,621 & $\mathbf{5 0 8}$ & .739 & .854 \\
Y1.8 & 73,20 & 9,537 & $\mathbf{5 1 3}$ & .751 & .804 \\
Y1.9 & 74,35 & 7,503 & $\mathbf{9 3 3}$ & .719 & .894 \\
Y1.10 & 73,60 & 8,147 & $\mathbf{4 8 8}$ & .751 & .875 \\
Y1.11 & 73,55 & 9,313 & $\mathbf{5 0 6}$ & .719 & .847 \\
Y1.12 & 74,60 & 6,779 & $\mathbf{8 5 2}$ & .881 & .823 \\
\hline
\end{tabular}

Sumber : Data Olahan SPSS Versi 24.0

Berdasarkan tabel diatas, seluruh item pertanyaan untuk variabel $\mathrm{X}$ dan variabel $Y$ nilai koefisien $r_{\text {hitung }}>r_{\text {tabel, }}$, sehingga dapat dinyatakan bahwa semua item pertanyaan adalah valid dan dapat dijadikan sebagai instrument penelitian. Hal ini dapat dilihat pada kolom Corrected Item-Total Correlation yang menunjukkan validitas butir pertanyaan yang lebih besar dari 0,468. Dengan demikian dapat disimpulkan intrumen penelitian valid, karena $r$ hitung lebih besar dari $r$ tabel

\section{b. Uji Reliabilitas}

Reliabilitas dihitung dengan metode Cronbach's Alpha Based on Standardized items sebesar 0,728>0,468 hal ini berarti instrument dinyatakan reliabel. Berikut adalah hasil pengujian Cronbach's Alpha Based on Standardized items yang dianalisis dengan menggunakan SPSS versi 24.0.

\section{Tabel 2. Uji Reliabilitas Instrumen}

\section{Reliability Statistics}

\begin{tabular}{|c|r|c|}
\hline $\begin{array}{c}\text { Cronbach's } \\
\text { Alpha }\end{array}$ & $\begin{array}{c}\text { Cronbach's } \\
\text { Alpha Based on } \\
\text { Standardized } \\
\text { Items }\end{array}$ & N of Items \\
\hline .725 & .728 & 22 \\
\hline \multicolumn{2}{|c|}{ Sumber : Data Olahan SPSS Versi 24.0 }
\end{tabular}

Berdasarkan tabel di atas di ketahui nilai Cronbach's Alpha Based on Standardized items pada penelitian ini sebesar $0,728>0,468$. Sehingga dapat dinyatakan bahwa semua instrumen penelitian ini adalah reliabel. 


\section{c. Uji Normalitas}

Uji normalitas digunakan untuk mengetahui apakah populasi data berdistribusi normal atau tidak Siregar (2015). Uji normalitas digunakan dalam penelitian ini adalah one sample Kolmogrov-Smirnov dengan menggunakan taraf signifikasi 0,05. Data dinyatakan berdistribusi normal jika signifikasi lebih besar dari $5 \%$ atau 0,05 .

Tabel 3. Uji Normalitas

One-Sample Kolmogorov-Smirnov Test

\begin{tabular}{|l|l|r|r|}
\hline \multicolumn{2}{|l|}{} & \multicolumn{1}{|c|}{ x } & \multicolumn{1}{|c|}{ y } \\
\hline \multirow{2}{*}{ Normal Parameters } \\
& Mean & 95 & 95 \\
\cline { 2 - 4 } & Std. Deviation & 34,80 & 46,95 \\
\hline \multirow{2}{*}{ Most Extreme Differences } & Absolute & 2,118 & 1,932 \\
\cline { 2 - 4 } & Positive &, 185 &, 140 \\
\cline { 2 - 4 } & Negative &,- 185 &, 140 \\
\hline Test Statistic & &, 185 &,- 111 \\
\hline Asymp. Sig. (2-tailed) &, $070^{\mathrm{c}}$ &, $200^{\mathrm{c}, \mathrm{d}}$ \\
\hline
\end{tabular}
a. Test distribution is Normal.
b. Calculated from data.
c. Lilliefors Significance Correction.
d. This is a lower bound of the true significance.
Sumber : Data Olahan SPSS Versi 24.0

Berdasarkan tabel sample Kolmogrov-Smirnov atau Asymp. Sig. (2-tailed). Nilai ini di bandingkan dengan 0,05 atau menggunakan taraf signifikasi 5\%. Dengan pedoman pengambilan keputusan jika Asymp. Sig. (2-tailed) $>0,05$ maka distribusi data normal dan jika Asymp. Sig. (2-tailed) $<0,05$ maka distribusi data tidak normal. Dilihat dari tabel 25 menunjukan bahwa distribusi data normal. Dengan demikian, proses pengolahan data dapat dilanjutkan ke tahap berikutnya yaitu analisis regresi linear sederhana.

\section{Deskripsi Data}

\section{a. Variabel X (Rekrutmen)}

Peneliti dalam hal ini akan menjelaskan deskripsi jawaban responden pada tabeltabel sebagai berikut:

Tabel 3. Proses Rekrutmen Sangat Baik(X1.1)

\begin{tabular}{|c|c|c|c|c|}
\hline & Frequency & Percent & Valid Percent & $\begin{array}{l}\text { Cumulative } \\
\text { Percent }\end{array}$ \\
\hline Valid & 8 & 8,4 & 8,4 & 8,4 \\
\hline
\end{tabular}




\begin{tabular}{|l|l|r|r|r|r|}
\hline RG & 15 & 15,8 & 15,8 & 24,2 \\
\hline S & 65 & 68,4 & 68,4 & 92,6 \\
\cline { 2 - 5 } SS & 7 & 7,4 & 7,4 & 100,0 \\
\cline { 2 - 6 } & Total & 95 & 100,0 & 100,0 & \\
\hline
\end{tabular}

Sumber : Data Olahan SPSS Versi 24.0

Dari tabel di atas, dapat di jelaskan bahwa yang memilih opsi STS (nilainya 1) tidak ada, untuk opsi TS (nilainya 2) sebanyak 8 responden atau sebesar $8,4 \%$, untuk opsi RG (nilainya 3 ) sebanyak 15 responden atau sebesar $15,8 \%$, untuk opsi $S$ (nilainya 4) sebanyak 65 responden atau sebesar $68,4 \%$, dan untuk opsi SS (nilainya 5) sebanyak 7 responden atau sebesar 7,4\%.

Tabel 4.Seleksi Bakal Calon Memenuhi Syarat (X1.2)

\begin{tabular}{|l|r|r|r|r|r|}
\hline \multicolumn{1}{|c|}{} & \multicolumn{1}{|c|}{ Frequency } & Percent & Valid Percent & \multicolumn{2}{c|}{$\begin{array}{c}\text { Cumulative } \\
\text { Percent }\end{array}$} \\
\hline Valid & TS & 7 & 7,4 & 7,4 & 7,4 \\
\cline { 2 - 6 } & RG & 17 & 17,9 & 17,9 & 25,3 \\
\cline { 2 - 6 } & S & 67 & 70,5 & 70,5 & 95,8 \\
\cline { 2 - 6 } & SS & 4 & 4,2 & 4,2 & 100,0 \\
\cline { 2 - 6 } & Total & 95 & 100,0 & 100,0 & \\
\hline
\end{tabular}

Sumber : Data Olahan SPSS Versi 24.0

Dari tabel di atas, dapat di jelaskan bahwa yang memilih opsi STS (nilainya 1) tidak ada, untuk opsi TS (nilainya 2) sebanyak 7 responden atau sebesar 7,4\%, untuk opsi RG (nilainya 3) sebanyak 17 responden atau sebesar 17,9\%, untuk opsi S (nilainya 4) sebanyak 67 responden atau sebesar $70,5 \%$, dan untuk opsi SS (nilainya 5) sebanyak 4 responden atau sebesar $4,2 \%$, pertanyaan 2 variabel $X$ (Rekrutmen).

Tabel 5. Pengumunan Hasil Test (X1.3)

\begin{tabular}{|l|r|r|r|r|r|}
\hline & & & & \multicolumn{1}{c|}{$\begin{array}{c}\text { Cumulative } \\
\text { Percent }\end{array}$} \\
\hline Valid & Frequency & Percent & Valid Percent & 21,1 \\
\cline { 2 - 6 } & TS & 20 & 21,1 & 21,1 & 38,9 \\
\cline { 2 - 6 } & RG & 17 & 17,9 & 17,9 & 98,9 \\
\cline { 2 - 6 } & SS & 57 & 60,0 & 60,0 & 100,0 \\
\cline { 2 - 6 } & Total & 95 & 100,0 & 100,0 & \\
\hline
\end{tabular}

Sumber : Data Olahan SPSS Versi 24.0

Dari tabel di atas, dapat di jelaskan bahwa yang memilih opsi STS (nilainya 1) tidak ada, untuk opsi TS (nilainya 2) sebanyak 20 responden atau sebesar $21,1 \%$, untuk opsi RG (nilainya 3) sebanyak 17 responden atau sebesar $17,9 \%$, untuk opsi S (nilainya 4) sebanyak 57 responden atau sebesar $60,0 \%$, dan untuk opsi SS (nilainya 5) sebanyak 1 responden atau sebesar $1,1 \%$. 
Tabel 6. Tanggung Jawab Terhadap Calon (X1.4)

\begin{tabular}{|l|l|r|r|r|r|}
\hline \multicolumn{2}{|c|}{} & Frequency & Percent & Valid Percent & $\begin{array}{c}\text { Cumulative } \\
\text { Percent }\end{array}$ \\
\hline \multirow{4}{*}{ Valid } & TS & 5 & 5,3 & 5,3 & 5,3 \\
\cline { 2 - 6 } & RG & 19 & 20,0 & 20,0 & 25,3 \\
\cline { 2 - 6 } & S & 67 & 70,5 & 70,5 & 95,8 \\
\cline { 2 - 6 } & SS & 4 & 4,2 & 4,2 & 100,0 \\
\cline { 2 - 6 } & Total & 95 & 100,0 & 100,0 & \\
\hline
\end{tabular}

Sumber : Data Olahan SPSS Versi 24.0

Dari tabel di atas, dapat di jelaskan bahwa yang memilih opsi STS (nilainya 1) tidak ada, untuk opsi TS (nilainya 2) sebanyak 5 responden atau sebesar 5,3\%, untuk opsi RG (nilainya 3) sebanyak 19 responden atau sebesar 20,0\%, untuk opsi S (nilainya 4) sebanyak 67 responden atau sebesar 70,5\%, dan untuk opsi SS (nilainya 5) sebanyak 4 responden atau sebesar 4,2\%.

Tabel 7. Selektif Dalam Memilih (X1.5)

\begin{tabular}{|c|c|c|c|c|c|}
\hline & & Frequency & Percent & Valid Percent & $\begin{array}{c}\text { Cumulative } \\
\text { Percent }\end{array}$ \\
\hline \multirow[t]{4}{*}{ Valid } & TS & 9 & 9,5 & 9,5 & 9,5 \\
\hline & RG & 26 & 27,4 & 27,4 & 36,8 \\
\hline & $S$ & 60 & 63,2 & 63,2 & 100,0 \\
\hline & Total & 95 & 100,0 & 100,0 & \\
\hline
\end{tabular}

Sumber : Data Olahan SPSS Versi 24.0

Dari tabel di atas, dapat di jelaskan bahwa yang memilih opsi STS (nilainya 1) tidak ada, untuk opsi TS (nilainya 2) sebanyak 9 responden atau sebesar 9,5\%, untuk opsi RG (nilainya 3) sebanyak 26 responden atau sebesar 27,4\%, untuk opsi S (nilainya 4) sebanyak 60 responden atau sebesar $63,2 \%$, dan untuk opsi SS (nilainya 5) tidak ada.

\section{Tabel 8. Menjalankan Tugas dengan Rasa Tanggung Jawab (X1.6)}

\begin{tabular}{|c|c|c|c|c|c|}
\hline & & Frequency & Percent & Valid Percent & $\begin{array}{c}\text { Cumulative } \\
\text { Percent }\end{array}$ \\
\hline \multirow[t]{5}{*}{ Valid } & TS & 5 & 5,3 & 5,3 & 5,3 \\
\hline & $R G$ & 19 & 20,0 & 20,0 & 25,3 \\
\hline & S & 68 & 71,6 & 71,6 & 96,8 \\
\hline & SS & 3 & 3,2 & 3,2 & 100,0 \\
\hline & Total & 95 & 100,0 & 100,0 & \\
\hline
\end{tabular}

Sumber : Data Olahan SPSS Versi 24.0

Dari tabel di atas, dapat di jelaskan bahwa yang memilih opsi STS (nilainya 1) tidak ada, untuk opsi TS (nilainya 2) sebanyak 5 responden atau sebesar 5,3\%, untuk opsi RG (nilainya 3) sebanyak 19 responden atau sebesar 20,0\%, untuk opsi S (nilainya 4) sebanyak 68 responden atau sebesar $71,6 \%$, dan untuk opsi SS (nilainya 5) sebanyak 3 responden atau sebesar 3,2\%. 
Tabel 9. Bersikap Adil (X1.7)

\begin{tabular}{|l|l|r|r|r|r|}
\hline \multicolumn{2}{|c|}{} & & & & \multicolumn{2}{c|}{ Cumulative } \\
Valid & Frequency & Percent & Valid Percent & Percent \\
\cline { 2 - 6 } & RG & 32 & 33,7 & 33,7 & 33,7 \\
\cline { 2 - 6 } & S & 39 & 41,1 & 41,1 & 74,7 \\
\cline { 2 - 6 } & Total & 95 & 100,0 & 100,0 & 100,0 \\
\hline
\end{tabular}

Sumber : Data Olahan SPSS Versi 24.0

Dari tabel di atas, dapat di jelaskan bahwa yang memilih opsi STS (nilainya 1) tidak ada, untuk opsi TS (nilainya 2) sebanyak 32 responden atau sebesar 33,7\%, untuk opsi RG (nilainya 3) sebanyak 39 responden atau sebesar $41,1 \%$, untuk opsi $S$ (nilainya 4) sebanyak 24 responden atau sebesar $25,3 \%$, dan untuk opsi SS (nilainya 5) tidak ada.

\section{Tabel 10. Anggota Panitia Pemilihan Dari Masyarakat (X1.8)}

\begin{tabular}{|c|c|c|c|c|c|}
\hline & & Frequency & Percent & Valid Percent & $\begin{array}{l}\text { Cumulative } \\
\text { Percent }\end{array}$ \\
\hline Valid & TS & 19 & 20,0 & 20,0 & 20,0 \\
\hline & $\overline{R G}$ & 19 & 20,0 & 20,0 & 40,0 \\
\hline & $S$ & 57 & 60,0 & 60,0 & 100,0 \\
\hline & Total & 95 & 100,0 & 100,0 & \\
\hline
\end{tabular}

Sumber : Data Olahan SPSS Versi 24.0

Dari tabel di atas, dapat di jelaskan bahwa yang memilih opsi STS (nilainya 1) tidak ada, untuk opsi TS (nilainya 2) sebanyak 19 responden atau sebesar 20,0\%, untuk opsi RG (nilainya 3) sebanyak 19 responden atau sebesar 20,0\%, untuk opsi S (nilainya 4) sebanyak 57 responden atau sebesar $60,0 \%$, dan untuk opsi SS (nilainya 5) tidak ada.

Tabel 11. Kerahasian Soal Test (X1.9)

\begin{tabular}{|c|c|c|c|c|c|}
\hline & & Frequency & Percent & Valid Percent & $\begin{array}{l}\text { Cumulative } \\
\text { Percent }\end{array}$ \\
\hline \multirow[t]{4}{*}{ Valid } & TS & 5 & 5,3 & 5,3 & 5,3 \\
\hline & $\mathrm{RG}$ & 47 & 49,5 & 49,5 & 54,7 \\
\hline & $S$ & 43 & 45,3 & 45,3 & 100,0 \\
\hline & Total & 95 & 100,0 & 100,0 & \\
\hline
\end{tabular}

Sumber : Data Olahan SPSS Versi 24.0

Dari tabel di atas, dapat di jelaskan bahwa yang memilih opsi STS (nilainya 1) tidak ada, untuk opsi TS (nilainya 2) sebanyak 5 responden atau sebesar 5,3\%, untuk opsi RG (nilainya 3 ) sebanyak 47 responden atau sebesar $49,5 \%$, untuk opsi $S$ (nilainya 4) sebanyak 43 responden atau sebesar $45,3 \%$, dan untuk opsi SS (nilainya 5) tidak ada. 
Tabel 12. Sanksi Konkrit (X1.10)

\begin{tabular}{|l|l|r|r|r|r|}
\hline \multicolumn{2}{|c|}{} & & & & \multicolumn{2}{c|}{ Cumulative } \\
Valid & Frequency & \multicolumn{1}{c|}{ Percent } & Valid Percent & Percent \\
\cline { 2 - 6 } & RG & 11 & 11,6 & 11,6 & 11,6 \\
\cline { 2 - 6 } & S & 36 & 37,9 & 37,9 & 49,5 \\
\cline { 2 - 6 } & Total & 98 & 50,5 & 50,5 & 100,0 \\
\hline
\end{tabular}

Sumber : Data Olahan SPSS Versi 24.0

Dari tabel di atas, dapat di jelaskan bahwa yang memilih opsi STS (nilainya 1) tidak ada, untuk opsi TS (nilainya 2) sebanyak 11 responden atau sebesar 11,6\%, untuk opsi RG (nilainya 3) sebanyak 36 responden atau sebesar 37,9\%, untuk opsi S (nilainya 4) sebanyak 48 responden atau sebesar $50,5 \%$, dan untuk opsi SS (nilainya 5) tidak ada.

\section{b. Variabel Y (Kinerja)}

Peneliti dalam hal ini akan menjelaskan deskripsi jawaban responden pada tabeltabel sebagai berikut:

Tabel 13. Tugas Terlaksana Dengan Baik (Y1.1)

\begin{tabular}{|c|c|c|c|c|c|}
\hline & & Frequency & Percent & Valid Percent & $\begin{array}{c}\text { Cumulative } \\
\text { Percent }\end{array}$ \\
\hline Valid & $S$ & 78 & 82,1 & 82,1 & 82,1 \\
\hline & SS & 17 & 17,9 & 17,9 & 100,0 \\
\hline & Total & 95 & 100,0 & 100,0 & \\
\hline
\end{tabular}

Dari tabel di atas, dapat di jelaskan bahwa yang memilih opsi STS (nilainya 1) tidak ada, untuk opsi TS (nilainya 2) tidak ada, untuk opsi RG (nilainya 3) tidak ada, untuk opsi S (nilainya 4) sebanyak 78 responden atau sebesar $82,1 \%$, dan untuk opsi SS (nilainya 5) sebanyak 17 responden atau sebesar $17,9 \%$.

Tabel 14. Tanggung Jawab Kemajuan Desa (Y1.2)

\begin{tabular}{|c|c|c|c|c|c|}
\hline & & Frequency & Percent & Valid Percent & $\begin{array}{l}\text { Cumulative } \\
\text { Percent }\end{array}$ \\
\hline Valid & TS & 2 & 2,1 & 2,1 & 2,1 \\
\hline & $\mathrm{RG}$ & 9 & 9,5 & 9,5 & 11,6 \\
\hline & $S$ & 64 & 67,4 & 67,4 & 78,9 \\
\hline & SS & 20 & 21,1 & 21,1 & 100,0 \\
\hline & Total & 95 & 100,0 & 100,0 & \\
\hline
\end{tabular}

Sumber : Data Olahan SPSS Versi 24.0

Dari tabel di atas, dapat di jelaskan bahwa yang memilih opsi STS (nilainya 1) tidak ada, untuk opsi TS (nilainya 2) sebanyak 2 responden atau sebesar 2,1\%, untuk opsi RG (nilainya 3) sebanyak 9 responden atau sebesar 9,5\%, untuk opsi S 
(nilainya 4) sebanyak 78 responden atau sebesar $82,1 \%$, dan untuk opsi SS (nilainya 5) sebanyak 20 responden atau sebesar $21,1 \%$.

Tabel 15. Kedisiplinan (Y1.3)

\begin{tabular}{|l|l|l|l|l|l|}
\hline \multicolumn{2}{|c|}{} & Frequency & Percent & Valid Percent & $\begin{array}{l}\text { Cumulative } \\
\text { Percent }\end{array}$ \\
\hline \multirow{4}{*}{ Valid } & RG & 24 & 25,3 & 25,3 & 25,3 \\
\cline { 2 - 6 } & S & 64 & 67,4 & 67,4 & 92,6 \\
\cline { 2 - 6 } & SS & 7 & 7,4 & 7,4 & 100,0 \\
\cline { 2 - 5 } & Total & 95 & 100,0 & 100,0 & \\
\hline
\end{tabular}

Sumber : Data Olahan SPSS Versi 24.0

Dari tabel di atas, dapat di jelaskan bahwa yang memilih opsi STS (nilainya 1) tidak ada, untuk opsi TS (nilainya 2) tidak ada, untuk opsi RG (nilainya 3) sebanyak 24 responden atau sebesar 25,3\%, untuk opsi S (nilainya 4) sebanyak 64 responden atau sebesar $67,4 \%$, dan untuk opsi SS (nilainya 5 ) sebanyak 7 responden atau sebesar $7,4 \%$.

Tabel 16. Pelayanan Yang Baik (Y1.4)

\begin{tabular}{|l|l|r|r|r|r|}
\hline \multicolumn{2}{|c|}{} & Frequency & Percent & Valid Percent & $\begin{array}{c}\text { Cumulative } \\
\text { Percent }\end{array}$ \\
\hline \multirow{4}{*}{ Valid } & TS & 30 & 31,6 & 31,6 & 31,6 \\
\cline { 2 - 6 } & RG & 20 & 21,1 & 21,1 & 52,6 \\
\cline { 2 - 6 } & S & 45 & 47,4 & 47,4 & 100,0 \\
\cline { 2 - 6 } & Total & 95 & 100,0 & 100,0 & \\
\hline
\end{tabular}

Sumber : Data Olahan SPSS Versi 24.0

Dari tabel di atas, dapat di jelaskan bahwa yang memilih opsi STS (nilainya 1) tidak ada, untuk opsi TS (nilainya 2) sebanyak 30 responden atau sebesar $31,6 \%$, untuk opsi RG (nilainya 3) sebanyak 20 responden atau sebesar $21,1 \%$, untuk opsi S (nilainya 4) sebanyak 45 responden atau sebesar $47,4 \%$, dan untuk opsi SS (nilainya 5) tidak ada.

Tabel 17. Efektif dan Efesien (Y1.5)

\begin{tabular}{|l|l|r|r|r|r|}
\hline \multicolumn{2}{|c|}{} & Frequency & Percent & Valid Percent & $\begin{array}{c}\text { Cumulative } \\
\text { Percent }\end{array}$ \\
\hline \multirow{3}{*}{ Valid } & RG & 19 & 20,0 & 20,0 & 20,0 \\
\cline { 2 - 6 } & S & 76 & 80,0 & 80,0 & 100,0 \\
\cline { 2 - 6 } & Total & 95 & 100,0 & 100,0 & \\
\hline
\end{tabular}

Sumber : Data Olahan SPSS Versi 24.0

Dari tabel di atas, dapat di jelaskan bahwa yang memilih opsi STS (nilainya 1) tidak ada, untuk opsi TS (nilainya 2) tidak ada, untuk opsi RG (nilainya 3) sebanyak 19 responden atau sebesar 20,0\%, untuk opsi S (nilainya 4) sebanyak 76 responden atau sebesar 80,0\%, dan untuk opsi SS (nilainya 5) tidak ada. 
Tabel 18. Standar Operasional Prosedur (Y1.6)

\begin{tabular}{|l|l|r|r|r|r|}
\hline \multicolumn{2}{|c|}{} & Frequency & Percent & Valid Percent & $\begin{array}{c}\text { Cumulative } \\
\text { Percent }\end{array}$ \\
\hline \multirow{4}{*}{ Valid } & RG & 11 & 11,6 & 11,6 & 11,6 \\
\cline { 2 - 6 } & S & 75 & 78,9 & 78,9 & 90,5 \\
\cline { 2 - 6 } & SS & 9 & 9,5 & 9,5 & 100,0 \\
\cline { 2 - 6 } & Total & 95 & 100,0 & 100,0 & \\
\hline
\end{tabular}

Sumber : Data Olahan SPSS Versi 24.0

Dari tabel di atas, dapat di jelaskan bahwa yang memilih opsi STS (nilainya 1) tidak ada, untuk opsi TS (nilainya 2) tidak ada, untuk opsi RG (nilainya 3) sebanyak 11 responden atau sebesar 11,6\%, untuk opsi S (nilainya 4) sebanyak 75 responden atau sebesar 78,9\%, dan untuk opsi SS (nilainya 5) sebanyak 9 responden atau sebesar $9,5 \%$.

Tabel 19. Melihat Status Sosial Masyarakat Dilayani (Y1.7)

\begin{tabular}{|l|r|r|r|r|r|}
\hline \multicolumn{2}{|c|}{} & Frequency & Percent & Valid Percent & $\begin{array}{c}\text { Cumulative } \\
\text { Percent }\end{array}$ \\
\hline \multirow{3}{*}{ Valid } & S & 67 & 70,5 & 70,5 & 70,5 \\
\cline { 2 - 6 } & SS & 28 & 29,5 & 29,5 & 100,0 \\
\cline { 2 - 5 } & Total & 95 & 100,0 & 100,0 & \\
\hline
\end{tabular}

Dari tabel di atas, dapat di jelaskan bahwa yang memilih opsi STS (nilainya 1) tidak ada, untuk opsi TS (nilainya 2) tidak ada, untuk opsi RG (nilainya 3) tidak ada, untuk opsi S (nilainya 4) sebanyak 67 responden atau sebesar 70,5\%, dan untuk opsi SS (nilainya 5) sebanyak 28 responden atau sebesar $29,5 \%$.

Tabel 20. Bahasa yang Baik (Y1.8)

\begin{tabular}{|l|l|r|r|r|r|}
\hline \multicolumn{2}{|c|}{} & Frequency & Percent & Valid Percent & $\begin{array}{c}\text { Cumulative } \\
\text { Percent }\end{array}$ \\
\hline \multirow{3}{*}{ Valid } & S & 58 & 61,1 & 61,1 & 61,1 \\
\cline { 2 - 6 } & SS & 37 & 38,9 & 38,9 & 100,0 \\
\cline { 2 - 6 } & Total & 95 & 100,0 & 100,0 & \\
\hline
\end{tabular}

Sumber : Data Olahan SPSS Versi 24.0

Dari tabel di atas, dapat di jelaskan bahwa yang memilih opsi STS (nilainya 1) tidak ada, untuk opsi TS (nilainya 2) tidak ada, untuk opsi RG (nilainya 3) tidak ada, untuk opsi S (nilainya 4) sebanyak 58 responden atau sebesar 61,1\%, dan untuk opsi SS (nilainya 5) sebanyak 37 responden atau sebesar 38,9\%.

Tabel 21. Pelayanan Tepat Sasaran (Y1.9)

\begin{tabular}{|l|l|r|r|r|r|}
\hline \multicolumn{2}{|c|}{} & Frequency & Percent & Valid Percent & $\begin{array}{c}\text { Cumulative } \\
\text { Percent }\end{array}$ \\
\hline \multirow{4}{*}{ Valid } & TS & 29 & 30,5 & 30,5 & 30,5 \\
\cline { 2 - 6 } & RG & 25 & 26,3 & 26,3 & 56,8 \\
\cline { 2 - 6 } & S & 37 & 38,9 & 38,9 & 95,8 \\
\cline { 2 - 6 } & SS & 4 & 4,2 & 4,2 & 100,0 \\
\cline { 2 - 6 } & Total & 95 & 100,0 & 100,0 & \\
\hline
\end{tabular}

Sumber : Data Olahan SPSS Versi 24.0 
Dari tabel di atas, dapat di jelaskan bahwa yang memilih opsi STS (nilainya 1) tidak ada, untuk opsi TS (nilainya 2) sebanyak 29 responden atau sebesar 30,5\%, untuk opsi RG (nilainya 3) sebanyak 25 responden atau sebesar 26,3\%, untuk opsi S (nilainya 4) sebanyak 37 responden atau sebesar 38,9\%, dan untuk opsi SS (nilainya 5) sebanyak 4 responden atau sebesar 4,2\%.

Tabel 22. Pelayanan Cepat Dan Tepat (Y1.10)

\begin{tabular}{|l|l|r|r|r|r|}
\hline \multicolumn{2}{|c|}{} & Frequency & Percent & Valid Percent & $\begin{array}{c}\text { Cumulative } \\
\text { Percent }\end{array}$ \\
\hline \multirow{3}{*}{ Valid } & S & 74 & 77,9 & 77,9 & 77,9 \\
\cline { 2 - 6 } & SS & 21 & 22,1 & 22,1 & 100,0 \\
\cline { 2 - 6 } & Total & 95 & 100,0 & 100,0 & \\
\hline
\end{tabular}

Dari tabel di atas, dapat di jelaskan bahwa yang memilih opsi STS (nilainya 1) tidak ada, untuk opsi TS (nilainya 2) tidak ada, untuk opsi RG (nilainya 3) tidak ada, untuk opsi S (nilainya 4) sebanyak 74 responden atau sebesar 77,9\%, dan untuk opsi SS (nilainya 5) sebanyak 21 responden atau sebesar 22,1\%.

Tabel 23. Penguasaan Tugas (Y1.11)

\begin{tabular}{|l|l|r|r|r|r|}
\hline \multicolumn{2}{|c|}{} & Frequency & Percent & Valid Percent & $\begin{array}{c}\text { Cumulative } \\
\text { Percent }\end{array}$ \\
\hline \multirow{3}{*}{ Valid } & S & 76 & 80,0 & 80,0 & 80,0 \\
\cline { 2 - 6 } & SS & 19 & 20,0 & 20,0 & 100,0 \\
\cline { 2 - 6 } & Total & 95 & 100,0 & 100,0 & \\
\hline
\end{tabular}

Sumber : Data Olahan SPSS Versi 24.0

Dari tabel di atas, dapat di jelaskan bahwa yang memilih opsi STS (nilainya 1) tidak ada, untuk opsi TS (nilainya 2) tidak ada, untuk opsi RG (nilainya 3) tidak ada, untuk opsi S (nilainya 4) sebanyak 76 responden atau sebesar 80,0\%, dan untuk opsi SS (nilainya 5) sebanyak 19 responden atau sebesar 20,0\%.

Tabel 24. Penyelesaian Tepat Waktu (Y1.12)

\begin{tabular}{|l|r|r|r|r|r|}
\hline \multirow{2}{*}{} & Frequency & Percent & Valid Percent & $\begin{array}{c}\text { Cumulative } \\
\text { Percent }\end{array}$ \\
\hline \multirow{4}{*}{ Valid } & TS & 24 & 25,3 & 25,3 & 25,3 \\
\cline { 2 - 6 } & RG & 22 & 23,2 & 23,2 & 48,4 \\
\cline { 2 - 6 } & S & 49 & 51,6 & 51,6 & 100,0 \\
\cline { 2 - 6 } & Total & 95 & 100,0 & 100,0 & \\
\hline \multicolumn{2}{|c|}{ Sumber : Data Olahan SPSS Versi 24.0 }
\end{tabular}

Dari tabel di atas, dapat di jelaskan bahwa yang memilih opsi STS (nilainya 1) tidak ada, untuk opsi TS (nilainya 2) sebanyak 24 responden atau sebesar 25,3\%, untuk opsi RG (nilainya 3) sebanyak 22 responden atau sebesar 23,2\%, untuk opsi S (nilainya 4) sebanyak 49 responden atau sebesar $51,6 \%$, dan untuk opsi SS (nilainya 5) tidak ada. 


\section{Analisis Regresi Linear Sederhana}

Analisis regresi linear sederhana merupakan analisis data untuk melihat apakah ada pengaruh variabel $X$ terhadap variabel $Y$. Hasil perhitungan analisis regresi sederhana melalui SPSS, maka diperoleh nilai-nilai untuk variabel bebas dan variabel terikat dapat dilihat pada tabel berikut:

\section{Tabel 25. Uji Regresi Linear Sederhana}

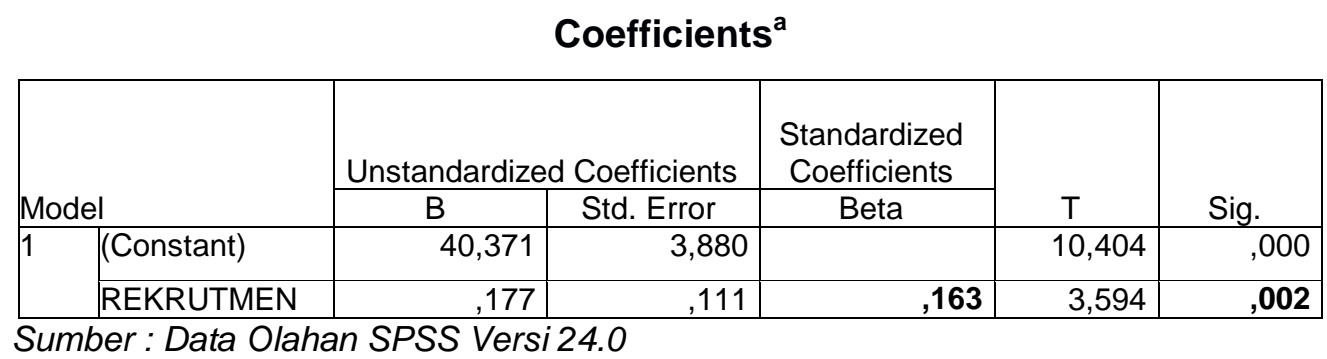

Adapun proses pengambilan keputusan regresi linear sederhana dapat di lakukan juga dengan membandingkan signifikansi (sig) dengan 0,05 hasil output SPSS adalah:

1. Jika nilai signifikansi ( $\mathrm{sig}$ ) lebih kecil $<$ dari probabilitas 0,05 mengandung arti bahwa ada pengaruh rekrutmen $(\mathrm{X})$ terhadap kinerja $(\mathrm{Y})$.

2. Jika nilai signifikansi (sig) lebih besar $>$ dari probabilitas 0,05 mengandung arti bahwa tidak ada pengaruh rekrutmen $(\mathrm{X})$ terhadap kinerja $(\mathrm{Y})$.

Dari tabel diatas dapat di jelaskan bahwa nilai sig $0.002<0,05$ yang berarti rekrutmen $(\mathrm{X})$ berpengaruh terhadap kinerja $(\mathrm{Y})$. Dengan demikian juga berdasarkan tabel diatas, maka dapat disusun persamaan regresi sederhana sebagai berikut:

$\mathrm{Y}=\mathrm{a}+\mathrm{bX}$

$Y=40.371+0,177 X$

Artinya angka-angka dalam persamaan regresi diatas adalah:

1) Nilai a (konstanta) $=40.371$, menunjukkan bahwa apabila nilai variabel $\mathrm{X}=0$, maka nilai variabel $\mathrm{Y}$ sebesar 40.371 .

2) Nilai $b$ (koefisien regresi) $=0,177$, menunjukkan bahwa apabila nilai variabel $\mathrm{X}$ meningkat dengan satu-satuan, maka variabel $\mathrm{Y}$ akan mengalami peningkatan sebesar 0,177 satuan dengan asumsi variabel $\mathrm{X}$ tetap atau konsisten. Maka dapat dikatakan koefisien bernilai positif 
antara variabel $X$ dengan variabel $Y$, setiap peningkatan variabel $X$ sebesar 1 satuan akan meningkatkan variabel $Y$.

Gambar 1. Scatter-Plot

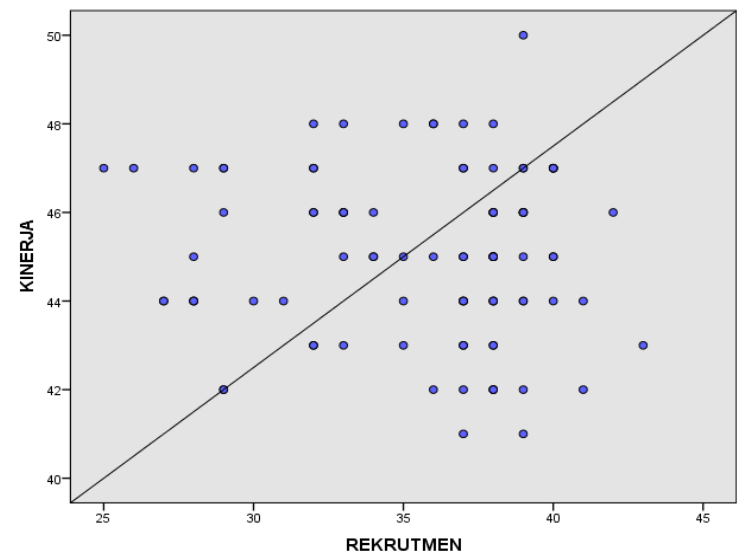

Sumber : Data Olahan SPSS Versi 24.0

Pada grafik diatas menunjukkan area penerimaan hipotesis penelitian yang di ajukan oleh peneliti yaitu Ada pengaruh positif rekrutmen perangkat desa terhadap kinerja perangkat desa di Desa Sungai Tohor Barat dan Desa Sendanu Darul Ihsan. Posisi Scater plot menunjukkan adanya hubungan posistif antara rekrutmen dengan kinerja namun nilainya tidak kuat hanya sebesar 0,163.

\section{KESIMPULAN}

Berdasarkan uraian pada hasil penelitian dan pembahasan, penulis menarik sebuah kesimpulan bahwa rekrutmen perangkat desa sangat penting dalam menentukan kinerja suatu perangkat desa. Hal ini dapat digambarkan melalui uji hipotesis yang dimana meunjukkan adanya sebuah pengaruh antara rekrutmen perangkat desa terhadap kinerja perangkat desa. Dilihat dari nilai sig $0.002<0,05$ yang berarti rekrutmen $(X)$ berpengaruh terhadap kinerja $(Y)$. Pengaruh yang di dapati dari rekrutmen $(X)$ terhadap kinerja $(Y)$ sebesar 0,163 , dapat di kategorikan bahwa pengaruh rekrutmen perangkat desa terhadap kinerja di Desa Sungai Tohor Barat dan Desa Sendanu Darul Insan lemah dengan tingkat pengaruh sebesar 0,163 atau sebesar $16,3 \%$, selebihnya 0,837 atau sebesar $83,7 \%$ kinerja dipengaruhi oleh faktor-faktor lainnya, dengan keterbatasan peniliti hanya mengisyaratkan adakah pengaruh positif rekrutmen terhadap kinerja perangkat pemerintah Desa Sungai Tohor Barat dan Desa Sendanu Darul Ihsan. 
Berdasarkan kesimpulan yang telah di kemukakan di atas maka penulis mengajukan beberapa saran berikut:

1) Bagi pihak desa

Pemerintah desa merupakan suatu lembaga yang mengatur pemerintahan unit terkecil. Namun dalam mencari ataupun membuat kemajuan suatu desa sangat penting dengan aparatur desa yang baik, dengan demikian proses rekrutmen harus dilakukan dengan benar dan tidak ada lagi nepotisme dalam mencari aparatur desa demi kemajuan desa dan Negara Kesatuan Republik Indonesia.

2) Bagi masyarakat

Untuk masyarakat agar lebih partisipatif dalam kemajuan desa, baik hal terkecil maupun hal terbesar. Masyarakat merupakan salah satu pihak yang melakukan pengawasan terhadap kinerja perangkat desa. Begitu pula dengan proses rekrutmen agar desa benar benar di pimpin orang yang berkualitas dalam pengelolaan desa serta kemajuan desa.

3) Bagi peneliti selanjutnya

Bagi peneliti selanjutnya yang ingin meneliti topik yang sama agar dapat meneliti pengaruh variabel lain terhadap kinerja perangkat desa, seperti tingkat pendidikan perangkat desa, pengalaman, kondisi lingkungan kerja, kepemimpinan kepala desa, dan lain sebaginya.

\section{REFERENSI}

Arikunto, S. 2006. Prosedur Penelitian Suatu Pendekatan Praktek Edisi Revisi VI. Rineka cipta. Jakarta

Dwiyanto, Agus. 2008. Mewujudkan Good Governance Melalui Pelayanan Publik. Gadjah Mada University Press. Yogyakarta

Handoko, T. Hani. 2008. Manajemen Personalia dan Sumber Daya Manusia. BPFE. Yogyakarta

Hasibuan, Malayu S.P. 2005. Manajemen Sumber Daya Manusia, Edisi Revisi. Bumi Aksara. Jakarta

Mathis, R.L. \& J.H. jackson. 2006. Human Resource Management: Manajemen Sumber Daya Manusia. Terjemahan Dian Angelia. Salemba empat. Jakarta 
Mangkunegara, Anwar Prabu. 2005.Evaluasi Kinerja SDM. Refika Aditama. Bandung , 2009. Manajemen Sumber Daya Manusia Perusahaan, cetakan pertama, Penerbit :Remaja Rosdakarya, Bandung

Rivai, Veithzal. 2009. Manajemen Sumber Daya Manusia Untuk Perusahaan Dari Teori ke Praktik Raja Grafindo Persada. Jakarta

Simanjuntak, Payaman J. 2005. Manajemen dan Evaluasi Kinerja. FE UI. Jakarta

Simamora, Henry. 2004. Manajemen Sumber Daya Manusia. Gramedia Pustaka. Jakarta

Siregar, Sofyan. 2015. Statistik Parametrik Untuk Penelitian Kuantitatif. Bumi Aksara. Yogyakarta

Sukamti, Umi. 1989. Manajeman Personalia/Sumberdaya Manusia. Depdikbud Ditjend PPLPTK. Jakarta

Sugiyono. 2009. Metode Penelitian Administrasi :dilengkapi dengan Metode $R \& D$. Penerbit : Alfabeta. Bandung.

Supranto, J. 2011. StatistikTeori dan Aplikasi. UI Pres. Jakarta

Undang-Undang No. 23 Tahun 2014 tentang Pemerintah Daerah

Undang-Undang No. 6 Tahun 2014 tentang Desa

Peraturan Menteri Dalam Negeri (PERMENDAGRI) NO 83 Tahun 2015 mengenai Pengangkatan dan Pemberhentian Perangkat Desa

Widjaja, HAW. 2005. Otonomi Desa Merupakan Otonomi yang Asli Bulat dan Utuh. PT Raja Grafindo Persada. Jakarta 